\title{
Non-host disease resistance response in pea (Pisum sativum) pods: Biochemical function of DRR-206 and phytoalexin pathway localization
}

\author{
Herana Kamal Seneviratne, Doralyn S. Dalisay, Kye-Won Kim, Syed G.A. Moinuddin, Hong \\ Yang, Christopher M. Hartshorn, Laurence B. Davin and Norman G. Lewis* \\ Institute of Biological Chemistry, Washington State University, Pullman, WA 99164-6340, USA
}

In honour of Professor Vincenzo de Luca's $60^{\text {th }}$ birthday.

\begin{abstract}
*To whom correspondence should be addressed: Norman G. Lewis, Institute of Biological Chemistry, Washington State University, Pullman, WA 99164-3640, USA; Tel.: 1-509-3352682; Fax.: 1-509-335-8206; Email: lewisn@wsu.edu
\end{abstract}




\begin{abstract}
Continually exposed to potential pathogens, vascular plants have evolved intricate defense mechanisms to recognize encroaching threats and defend themselves. They do so by inducing a set of defense responses that can help defeat and/or limit effects of invading pathogens, of which the non-host disease resistance response is the most common. In this regard, pea (Pisum sativum) pod tissue, when exposed to Fusarium solani f. sp. phaseoli spores, undergoes an inducible transcriptional activation of pathogenesis-related genes, and also produces (+)-pisatin, its major phytoalexin. One of the inducible pathogenesis-related genes is Disease Resistance Response-206 (DRR206), whose role in vivo was unknown. DRR206 is, however, related to the dirigent protein (DP) family. In this study, its biochemical function was investigated in planta, with the metabolite associated with its gene induction being pinoresinol monoglucoside. Interestingly, both pinoresinol monoglucoside and (+)-pisatin were co-localized in pea pod endocarp epidermal cells, as demonstrated using matrix-assisted laser desorption/ionization (MALDI) imaging mass spectrometry. In addition, endocarp epidermal cells are also the site for both chalcone synthase and DRR206 gene expression. Taken together, these data indicate that both (+)-pisatin and pinoresinol monoglucoside function in the overall phytoalexin responses.
\end{abstract}

Keywords: Pea, Pisum sativum, Fabaceae, Fusarium solani f. sp. phaseoli, Dirigent protein, Pinoresinol, Pisatin, Pinoresinol monoglucoside, MALDI imaging mass spectrometry, Gene expression, Phytoalexin, Non-host disease response 


\section{Introduction}

Vascular plants possess a form of immunity, called non-host resistance, which helps protect against plant pathogens, and which involves induction of multiple defense genes including those for phytoalexin production (Hadwiger, 2008). When pea (Pisum sativum) pod tissue is exposed to Fusarium solani f. sp. phaseoli spores, a number of such genes are induced, several of whose cDNA clones have been isolated (Fristensky et al., 1988; Fristensky et al., 1985; Riggleman et al., 1985). Expression of one of these genes in vivo, Disease Resistance Response-206 (DRR206), was shown by Northern analysis to be induced to high, sustained, levels very early in pathogen exposure. A preliminary western analysis with rabbit polyclonal antibodies, directed against DRR206, indicated that it was approximately 23,000 Da (Culley et al., 1995). However, neither its biochemical nor physiological functions were established. In addition, this general defense response is associated with transcriptional activation of other pathogenesis-related (PR) genes, such as those encoding phenylalanine ammonia-lyase (PAL), chalcone synthase (CHS), DRR49, DRR276, chitinase, $\beta$-glucanase and defensins, as well as with accumulation of the phytoalexin, (+)-pisatin (1) (Scheme 1) (Hadwiger, 2008).

DRR206 (Wang and Fristensky, 2001) shares $\sim 60 \%$ sequence identity with the (+)pinoresinol forming dirigent protein (DP) (Fig. 1) (Halls et al., 2004), that was previously discovered in Forsythia sp. (Davin et al., 1997). The first example of a DP, the (+)-pinoresinol forming DP from Forsythia intermedia (Davin et al., 1997; Gang et al., 1999; Halls et al., 2004; Halls and Lewis, 2002), was established to be responsible for stereoselective control of coniferyl alcohol (2)-derived radical-radical coupling to afford (+)-pinoresinol (3a), in the presence of an one-electron oxidase or oxidant; DPs also appear to have a unique biochemical mechanism. While it is known that there are both (+)- and (-)-pinoresinol forming DPs (Davin et al., 1997; Gang et al., 1999; Kim et al., 2012; Pickel et al., 2010; Vassão et al., 2010), it is now evident from analyses of available EST databases, gene banks, and genome sequences, that multiple forms of DPs and their homologs are found in the plant kingdom (Davin and Lewis, 2000); the vast majority are yet of unknown biochemical/physiological functions, although various roles have been contemplated (Davin and Lewis, 2005; Hosmani et al., 2013).

The coniferyl alcohol (2)-derived dimer, pinoresinol (3), is a member of a large, structurally diverse, class of lignans, with these having a wide range of physiological and pharmacologically important properties (Chu et al., 1993). Because of their pronounced biological (antimicrobial, 

plants is to apparently help confer resistance against various opportunistic pathogens and predators.

The goal of this research was thus to determine the biochemical function of DRR206 in planta, and the identity and location of the metabolite(s) so produced and/or accumulating in situ on pathogen attack. In order to address this, recombinant DRR206 was initially obtained and its biochemical function was examined using the monolignols p-coumaryl (5) and coniferyl (2) alcohols as potential substrates. Next, pea pod tissue was exposed to $F$. solani f. sp. phaseoli spores, in order to detect and localize the metabolite(s) so produced. To do this, matrix-assisted laser desorption/ionization imaging mass spectrometry (MALDI IMS) was used for metabolite localization in situ, in addition to ultra-high performance liquid chromatography-mass spectrometry (UPLC-MS) electrospray ionization mass spectrometry (ESI-MS) coupled with ion mobility separation.

\section{Results and discussion}

\subsection{Gene expression analyses}

As a prelude to investigating the identity of the defense metabolite(s) being formed by DRR206, quantitative RT-PCR analyses were carried out to confirm induction of its mRNA expression levels at different time points/stages of fungal infection (Fig. 2). These analyses indicated that its mRNA expression was circa 5-6 fold higher (than an uninfected control) in pea pods after 6 hours of fungal exposure. This confirmed that induction of the DRR206 gene expression was due to fungal infection.

\subsection{Stereoselectivity of recombinant DRR206}

To identify the biochemical function of DRR206 in vitro, the DRR206 gene (lacking any intron) was cloned from pea leaf genomic DNA and recombinant DRR206 was produced in a tomato (Solanum peruvianum) cell suspension culture as DPs are glycosylated (Kim et al., 2012). It was then purified to apparent homogeneity (data not shown) using ammonium sulfate precipitation and two steps of cationic exchange column chromatographic steps. The purified recombinant DRR206 was next assayed for stereoselectivity of monolignol coupling, using $p$ coumaryl (5) and coniferyl (2) alcohols as substrates in vitro. No stereoselective coupling of $p$ - 

assay using DRR206 in the presence of a one electron oxidase (laccase) was racemic (data not shown). In contrast, stereoselective coupling of coniferyl alcohol (2) was clearly engendered, i.e. as established by formation of the (+)-antipode (3a) in $\sim 38 \%$ enantiomeric excess (e.e.) over its (-)-enantiomer (3b) at 6.4 $\mu$ M DRR206 (Fig. 3).

\subsection{Metabolite analyses}

Since DRR206 mRNA expression was increased by fungal infection, and assays of recombinant DRR206 in vitro resulted in stereoselective formation of (+)-pinoresinol (3a), pea pod tissue was next infected with $F$. solani to identify the chemical nature of any metabolite(s) whose levels were induced. Accordingly, changes in metabolite levels before and after fungal exposure were investigated by specifically targeting lignan-type molecules, using UPLC-HRMS, with analysis of uninfected pea pods performed as a control. From these analyses, the isoflavonoid (+)-pisatin (1) showed the most significant level of increase in infected pea pods over uninfected (control) pea pods (data not shown), and was also the most abundant. This observation was in agreement with previous studies (Banks and Dewick, 1983; Celoy and VanEtten, 2014; Cruickshank and R Perrin, 1963; DiCenzo and VanEtten, 2006; Hadwiger, 1966).

By contrast, no lignan aglycones (including pinoresinol (3)) were detected in the extracts examined under the conditions employed. However, since many lignans are sequestered in glycosidic form, the crude pea pod extracts were next treated with $\beta$-glucosidase to release aglycones and the metabolite analyses were again performed. One new metabolite was detected in infected (but not control) pea pod tissue which eluted at the same retention time as pinoresinol (3), and also had very similar electrospray mass fragments (Fig. S1B) to the authentic standard (Fig. S1A) (Yamamoto et al., 2010). Following its purification using reversed-phase HPLC (see "Experimental") and chiral HPLC, the pinoresinol (3) isolate was found to be in $84 \%$ e.e. of its (+)-form (3a) (Fig. S2B).

It was next instructive to establish the chemical nature of the pinoresinol (3) derivative produced in fungal infected pea pods. Accordingly, extracts of fungally infected and uninfected pea pods (without $\beta$-glucosidase treatment) were individually analyzed using UPLC-qToF-MS. A small new peak was detected in fungal infected pea pods (Fig. 4B, arrow), whose mass 

synthesis of an authentic standard (see "Experimental"). Among all the other peaks, this was the only one detected which corresponded to a lignan glycoside based on its retention time, UV and mass spectra. Both the purified metabolite from fungal infected pea pods and synthetic $\mathbf{4}$ were purified, with each individually subjected to ESI-qTOF- mass spectrometry analyses in the positive and negative ion modes. The qTOF-electrospray ionization MS of authentic 4 and the isolate from infected pea pod tissue in the positive ion mode gave molecular ion peaks at $\mathrm{m} / \mathrm{z}$ $543.1843(-0.1 \mathrm{ppm})[\mathrm{M}+\mathrm{Na}]^{+}$and $543.1844(-0.3 \mathrm{ppm})[\mathrm{M}+\mathrm{Na}]^{+}$, respectively (Fig. S3A and $\mathrm{S} 3 \mathrm{~B}$ ), these corresponding to the molecular formula $\mathrm{C}_{26} \mathrm{H}_{32} \mathrm{NaO}_{11}$. In the negative ion mode, authentic standard (4) and the isolate from infected pea pod tissue gave molecular ion peaks at $m / z 519.1866(0.0 \mathrm{ppm})[\mathrm{M}-\mathrm{H}]^{-}$and $519.1867(-0.1 \mathrm{ppm})[\mathrm{M}-\mathrm{H}]^{-}$, respectively (Fig. S3C and S3D).

Next, UPLC-qToF-MS coupled with ion mobility separation analyses were carried out in order to further confirm the identity of $\mathbf{4}$. This analytical technique gives an additional dimension of ion separation, based on charge, size and shape. This ability to exploit the collision crosssection (CCS) property of a compound results in the highest levels of separation, specificity, sensitivity and structural information. Furthermore, depending on the compound, it can also give isomer separation, elimination of interferences, and the ability to confirm identity through its CCS and drift time (time taken for an ion to drift through a buffer gas under influence of an electric field) measurements.

These analyses were also carried out in both positive and negative ion modes. In the positive ion mode, the isolate gave a molecular ion peak at $\mathrm{m} / z 543.1852(-1.8 \mathrm{ppm})[\mathrm{M}+\mathrm{Na}]^{+}$ corresponding to the molecular formula of $\mathrm{C}_{26} \mathrm{H}_{32} \mathrm{NaO}_{11}$ (Table 1), in excellent agreement with the authentic standard. In the negative ion mode, the isolate had a molecular ion peak at $\mathrm{m} / \mathrm{z}$ $519.1868(-0.3 \mathrm{ppm})[\mathrm{M}-\mathrm{H}]^{-}$, which also was well correlated with the authentic standard. Drift times of the purified 4 in both positive and negative ion modes (85.785 bins and 100.693 bins) were also in agreement with those of the authentic standard 4 ( 85.625 bins and 100.568 bins, respectively) (Table 1). Taken together, these results unambiguously confirmed the identity of the purified metabolite as pinoresinol monoglucoside (4).

Accordingly, based on UV, retention time (Fig. 4) and mass spectra (Fig. S3) comparisons with authentic standard $\mathbf{4}$, the metabolite formed in infected pea pod tissue was pinoresinol 

conditions employed, strongly suggests its formation was induced by fungal infection. Being present in very low amounts, however, it was only detected and identified using high sensitivity and high resolution chromatographic/mass spectroscopic techniques.

\subsection{Matrix-assisted laser desorption/ionization imaging mass spectrometric analyses}

MALDI IMS experiments were started by selecting and optimizing matrix conditions and other parameters, like laser energy on authentic, pure pisatin (1) and pinoresinol monoglucoside, (4) to determine their ionization patterns and to detect them at different sample concentrations. Initially, two commonly used MALDI matrices (2,5-dihydroxybenzoic acid, DHB; $\alpha$-cyano-4hydroxycinnamic acid, CHCA), reportedly useful for ionizing small molecules were tested. The best conditions from these experiments (i.e. DHB, $40 \mathrm{mg} / \mathrm{ml}$ in $\mathrm{MeOH}-\mathrm{H}_{2} \mathrm{O}$ (which contains 0.1\% TFA) $70: 30, \mathrm{v} / \mathrm{v}$ ) were utilized to study the precise localization of pisatin (1) and pinoresinol monoglucoside (4) in fungal infected pea pod tissue.

The pea pod wall is composed of three distinct tissue layers: exocarp, mesocarp, and endocarp (Atkins et al., 1977) (Fig. 5A). In the fungal non-host disease response model system, where the three regions are exposed, the endocarp tissue is the one known to result in the nonhost resistance response. Additionally, the endocarp consists of an inner epidermis, a mid-region of two to three layers of parenchyma, and an inner layer of sclerenchyma cells (Fig. 5A). In this work, the cell types in pea pod tissue involved in pisatin (1) and pinoresinol monoglucoside (4) formation and/or accumulation were next investigated. Accordingly, matrix-assisted laser desorption/ionization imaging mass spectrometry (MALDI IMS) coupled with ion mobility separation was used to localize them in fungal infected pea pods (see "Experimental"). First, authentic pisatin (1) and pinoresinol monoglucoside (4) standards were tested, with ions $\mathrm{m} / z$ $297.0749(4.7 \mathrm{ppm})$ and $\mathrm{m} / \mathrm{z} 559.1594(-2.1 \mathrm{ppm})$ corresponding to $\left[\mathrm{M}-\mathrm{H}_{2} \mathrm{O}+\mathrm{H}\right]^{+}$for pisatin (1) and $[\mathrm{M}+\mathrm{K}]^{+}$for pinoresinol monoglucoside (4), respectively, being readily detected when using 2,5-dihydroxybenzoic acid (DHB) as matrix (Table 2) (Fig. S4 and S5).

In order to determine the spatial distribution of pisatin (1) and pinoresinol monoglucoside (4), surface sections from fungal infected pea pods were obtained. One of the major challenges encountered during MALDI imaging mass spectrometry analysis of pea pod surface sections was the low effectiveness of laser ablation on the tissue. This was because the surface sections were 

hexane dip (15 sec) prior to matrix application. Next, surface sections of an infected pea pod tissue, with and without epidermal cells, were examined by MALDI IMS; this (as expected) established the presence of hundreds of metabolites ranging from $\mathrm{m} / \mathrm{z}$ 100-1000 $\mathrm{Da}$ (data not shown).

Pisatin (1) was abundantly detected as its $\left[\mathrm{M}-\mathrm{H}_{2} \mathrm{O}+\mathrm{H}\right]^{+}$ion at $m / z 297.0753(3.3 \mathrm{ppm})$ in the endocarp epidermal cells, whereas pinoresinol monoglucoside (4) was detected as its potassium adduct at $m / z 559.1590(-1.4 \mathrm{ppm})$ in the same region (Table 2, Fig. 5B-G, and Fig. S4 and S5). The detection of pinoresinol monoglucoside (4) as its potassium adduct is provisionally explained by a high concentration of potassium salts in pea pod tissue. Furthermore, the $\mathrm{m} / z$ 297.0753 ion showed a drift time of 27.75 bins which is similar to that of the $\left[\mathrm{M}-\mathrm{H}_{2} \mathrm{O}+\mathrm{H}\right]^{+}$ion of the pisatin (1) authentic standard (27.85 bins). Similarly, the $m / z 559.1590$ ion had a drift time of 52.11 bins which is close to that of the $[\mathrm{M}+\mathrm{K}]^{+}$ion of the pinoresinol monoglucoside (4) authentic standard (51.93 bins) (Table 2; Fig. S4 and S5). Taken together, the above data further confirmed the identities of $\mathbf{1}$ and $\mathbf{4}$ in the fungal infected pea pod tissue, with the relative abundance of the former being circa 100 fold higher than pinoresinol monoglucoside (4) (Fig. 5B-G). Because of this, signal intensity counts for $\mathbf{4}$ were low compared to that of pisatin (1) (Fig. 5B-G).

Surface sections of uninfected pea pods, with and without endocarp epidermal cells, were also examined as a control. By contrast, although they also showed presence of hundreds of metabolites (data not shown), none apparently corresponded to either pisatin (1) or pinoresinol monoglucoside (4).

The MALDI IMS experiments showed localization of both pisatin (1) and pinoresinol monoglucoside (4) in the endocarp epidermal cell layer of pea pod tissue (Fig. 5B-G). However, MALDI images (single ion intensity maps) of pisatin (1) also showed low levels in the tissue with no epidermal cells (Fig. 5B, C and D). To further confirm and extend these observations, pea pods were fungally treated as before. Six hours after treatments the endocarp epidermal cell layer was removed from half of the pods, this resulting in 3 samples: the endocarp epidermal cell layers, and pods with/without endocarp epidermal cell layers. Comparable tissues were also obtained from uninfected pea pods. UPLC-qToF-MS metabolite analyses were next performed 

and 4 were present in the fungally infected endocarp epidermal cells (Figs. S6C, S6F, and S7F). Interestingly, pisatin (1) was also detected in very low abundance in pea pod tissue without the endocarp epidermal cells (Figs. S6B, S6E), and in minute amounts in non-infected tissues (Fig. S8, *). These observations thus presumably explain the presence of pisatin (1) in the mesocarp at very low ion abundance as demonstrated using MALDI IMS analysis (Fig. 5B-D). On the other hand, the UPLC-qToF-MS data indicated pinoresinol monoglucoside (4) was only present in endocarp epidermal cells (Fig. S7F) and not in the underlying tissue (S7E) or in the uninfected tissues (Figs. S7A-S7C).

It was next instructive to investigate the sites of biosynthesis of pisatin (1) and pinoresinol monoglucoside (4). In order to address this, quantitative RT-PCR analyses of the chalcone synthase $(C H S)$ gene, which is involved in pisatin (1) biosynthesis, and the DRR206 gene were carried out on various cell/tissue types including isolated epidermal cell layer, pea pod tissue without epidermal cell layer (mesocarp), and pea pod tissue with epidermal cell layer. Interestingly, both CHS and DRR206 genes showed highest expression levels in the endocarp epidermal cells (Fig. 6). These results indicated that both the biosynthesis and accumulation of pisatin (1) and pinoresinol monoglucoside (4) occur in the same cell type - the endocarp epidermal cells.

\subsection{Induction and spatial localization of defense compounds}

Plants can rapidly exploit their often distinctive metabolic toolsets to synthesize a fantastic armory of structurally and functionally diverse phytochemicals. Many are often required for their interactions with their environments, e.g. pathogen defense compounds (Bednarek and Osbourn, 2009; Dixon, 2001; Halkier and Gershenzon, 2006; Hammerschmidt, 1999; VanEtten et al., 1994). This, together with an ever-fluctuating biotic environment, imparts an evolutionary pressure upon plants to constantly create new phytochemicals, which help confer selective advantage to the plants. While these are essential for a plant's survival, this is only true under certain conditions when the pathogen is present (Lankau, 2007; Lankau and Strauss, 2007; Züst et al., 2012). Moreover, plants can attempt to resist microbial pathogenic attack using elaborate non-self-surveillance systems consisting of a repertoire of cell surface processes. Indeed, most 
Defense compounds attempt to terminate microbial colonization and often display highly localized accumulation at the site of infection, e.g. to attempt to sterilize the area against further pathogen entry (Smith, 1996). Indeed, many defense compounds are produced in a pathogeninducible manner (Bednarek et al., 2005; Churngchow and Rattarasarn, 2001; Zook and Hammerschmidt, 1997), suggesting that the production of toxic bioactive phytochemicals could have general significance for growth restriction of diverse pathogen classes. In this non-host resistance response, cytological studies on endocarp epidermal cells upon fungal infection have been investigated by Hadwiger and coworkers (Choi et al., 2001; Hadwiger et al., 1995; Teasdale et al., 1974), where changes in endocarp epidermal cells upon pathogenic attack were reported. These provide more evidence on the involvement of endocarp epidermal cells in plant defense responses.

Additionally, knowing the localization of phytochemicals in plants is important for further understanding their function, biosynthesis and possible transport within the plant. For example, some flavonoids and isoflavonoids, which are produced during this defense response and accumulate in the same cell type, are of environmental significance because they (or their aglycones) are biologically active (Dixon and Pasinetti, 2010; Harborne, 1994; Harborne and Williams, 2000). In this regard, both antifungal activity and mode of action of (+)-pinoresinol (3a) have been reported against several fungal strains including the human pathogen Candida albicans (Bomi et al., 2010). Therefore, it can provisionally be speculated that (+)-pinoresinol (3a) has an antifungal role in pea pods in vivo.

\section{Conclusion}

In this study, the metabolite associated with DRR206 induction was identified as pinoresinol monoglucoside (4), this being localized in the endocarp epidermal cell layer of pea pod tissue. To our knowledge, this is the first determination of the biochemical function of DRR206 as a (+) pinoresinol forming DP. Additionally, co-localization and co-induction of their formation on fungal exposure suggests both pisatin (1) and pinoresinol monoglucoside (4) are phytoalexins. Furthermore, a combination of high resolution chromatographic and advanced mass spectrometric techniques allowed a better understanding of non-host disease resistance. Such 
studies can, in turn, provide greater insights into how land plants adapted to terrestrial environments and dealt with the challenges presented.

\section{Experimental}

\subsection{Instrumentation and chromatography materials}

All solvents and chemicals used were either reagent or high performance liquid chromatography (HPLC) grade and purchased from Sigma-Aldrich (St. Louis, MO, USA), unless otherwise specified. Silica gel thin-layer chromatography (TLC) utilized Partisil ${ }^{\circledR}$ PK5F (Whatman; 20×20 cm, $1 \mathrm{~mm}, 150 \AA$ ) and AL SIL G/UV 254 (Whatman, 20×20 cm, 0.25 mm), whereas silica gel column chromatography (CC) employed silica gel 60 (EM Science). UV light and a $10 \% \mathrm{H}_{2} \mathrm{SO}_{4}$ spray followed by heating were used for TLC plate visualization. NMR spectra were recorded on an Inova $500 \mathrm{MHz}$ spectrometer operating at $499.85 \mathrm{MHz}\left({ }^{1} \mathrm{H}\right)$ and 125.67 MHz $\left({ }^{13} \mathrm{C}\right)$, respectively, with $J$ values given in Hz. Real time quantitative PCR analyses of gene expression were performed on a Mx3005 $\mathrm{P}^{\mathrm{TM}}$ real time PCR system (Stratagene, La Jolla, CA) with Platinum ${ }^{\circledR}$ SYBR $^{\circledR}$ Green qPCR SuperMixUDG (Invitrogen).

\subsection{Plant and fungal material}

Fusarium solani f. sp. phaseoli strain W-8 (ATCC no. 38135) (F. s. phas) was obtained as a gift from Prof. Lee A. Hadwiger, Department of Plant Pathology, Washington State University. The fungus was maintained at room temperature on potato dextrose agar $(30 \mathrm{~g} / \mathrm{L})$ (Beckton Dickinson, Sparks, MD, U.S.A) plates, to which was added a dry pea pod. Fungal macroconidia were harvested from 2 week old colonies for use as an inoculum. Pea pods were harvested from 4 week old $P$. sativum cv. Alcan plants grown in a greenhouse.

\subsection{Fungal inoculation of pea pods}

Immature pea pods, approximately 4.0-5.0 cm long, were split into halves, using a smooth surfaced spatula Freshly exposed endocarp tissue was inoculated with a F. solani f. sp. phaseoli spore suspension $(50 \mu \mathrm{l})\left(3.0 \times 10^{6}\right.$ spores $\left./ \mathrm{ml}\right)$ and allowed to incubate at $25^{\circ} \mathrm{C}$ in a moist chamber for $6 \mathrm{~h}$.

\subsection{Metabolite extraction}



individually centrifuged $(3000 \times \mathrm{g}$ for $5 \mathrm{~min})$ and evaporated to dryness in vacuo. Each extract was treated with $\beta$-glucosidase from almonds (Sigma; 7.4 units in $0.5 \mathrm{ml}$ of $\mathrm{NaOAc}$ buffer at $\mathrm{pH}$ 5.0) for $24 \mathrm{~h}$ at $37{ }^{\circ} \mathrm{C}$, with the resulting assay mixtures individually extracted using EtOAc as described in Nakatsubo et al. (2008). Samples were analyzed by UPLC-qToF-MS as described below.

\subsection{Metabolite analysis}

High-performance liquid chromatography (HPLC) analyses were performed using an Alliance 2690 HPLC system (Waters, Milford, MA), equipped with a photodiode array detector (Model 2990, Waters) with detection at $280 \mathrm{~nm}$. Reversed-phase separations were carried out with a Novapak $\mathrm{C}_{18}$ column (Waters; $150 \times 3.9 \mathrm{~mm}$ inner diameter). Elution conditions at a flow rate of $0.6 \mathrm{ml} \mathrm{min}{ }^{-1}$ were: linear gradients of $0.1 \% \mathrm{HCO}_{2} \mathrm{H}$ in $\mathrm{H}_{2} \mathrm{O}(\mathrm{A})$ and $0.1 \% \mathrm{HCO}_{2} \mathrm{H}$ in $\mathrm{CH}_{3} \mathrm{CN}$ (B) (Optima LC/MS, Fischer Scientific) from 90:10 to 60:40 in 19.50 min, then to 20:80 in $6 \mathrm{~min}$, to $0: 100$ in $3 \mathrm{~min}$ with this composition held for an additional $3 \mathrm{~min}$, and finally to 90:10 in $1.50 \mathrm{~min}$, with this being held for $12 \mathrm{~min}$. The (+) and (-)-enantiomers of pinoresinols (3a and 3b) were resolved on a Chiralcel OD (Chiral Technologies, West Chester, PA) column as described (Halls et al., 2004).

Plant extracts were analyzed using a Waters Acquity Ultra Performance Liquid Chromatography (UPLC) system equipped with a Waters BEH $\mathrm{C}_{18}$ column $(1.7 \mu \mathrm{m}$ particles, $2.1 \times 100 \mathrm{~mm}$ ) with a binary mobile phase of $0.1 \% \mathrm{HCO}_{2} \mathrm{H}$ in $\mathrm{H}_{2} \mathrm{O}(\mathrm{A})$ and $0.1 \% \mathrm{HCO}_{2} \mathrm{H}$ in $\mathrm{CH}_{3} \mathrm{CN}$ (B) with detection at $280 \mathrm{~nm}$ and by electrospray ionization qToF-mass spectrometry in both positive mode and negative modes separately. The gradient program was as follows: flow rate of $0.2 \mathrm{ml} \mathrm{min}^{-1}$; linear gradient of $\mathrm{A}$ : B from 90:10 to 60:40 in 6.50 min, to 20:80 in $2 \mathrm{~min}$, to $0: 100$ in $1 \mathrm{~min}$ followed by $1 \mathrm{~min}$ at 0:100, and finally to $90: 10$ in $0.5 \mathrm{~min}$ with this being held for $4 \mathrm{~min}$. The column temperature was kept at $25^{\circ} \mathrm{C}$ and sample injection volume was $5 \mu 1$. Masses were determined using a Waters Xevo G2 qToF mass spectrometer, using leucineenkephalin as a lock-mass standard, at a capillary voltage of $3 \mathrm{kV}$, cone voltage of $38 \mathrm{~V}$, a desolvation gas temperature of $280^{\circ} \mathrm{C}$ and source temperature of $100^{\circ} \mathrm{C}$. Masslynx V4.1 (Waters Corp.) was used to collect and process data. The chemical identities of the compounds observed 
were confirmed by comparing their MS/MS and $\mathrm{MS}^{\mathrm{n}}$ spectra (fragmentation pattern) with authentic standards. Identification of pisatin (1), pinoresinol (3) and pinoresinol monoglucoside (4) was done by comparing the retention time, UV, and MS spectra of authentic standards.

UPLC-qToF-MS coupled with ion mobility mass spectrometry experiments were performed on a Synapt G2 high-definition mass spectrometer (Waters Corp., Manchester, UK), a hybrid quadrupole/ion mobility/orthogonal time-of-flight mass spectrometer. The travelling wave ion mobility device employs dynamic electric fields under reduced pressures, with a trap and transfer cell located in front of, and after, the ion mobility separator, respectively. Collision-induced dissociation (CID) was initiated in the transfer cell by elevating collision energy (CE). A wave height of $40 \mathrm{~V}$ and a wave velocity of $1000.0 \mathrm{~ms}^{-1}$ were utilized for ion mobility separations (IMS) in both positive and negative ion modes. He was used as a drift gas at a flow rate of $90 \mathrm{ml}$ $\min ^{-1}$, resulting in a pressure of 3.5 mbar in the ion mobility device. Masslynx V4.1 (Waters Corp.) was used to collect and process data. Chemical identity of metabolites was confirmed by comparing ion mobility $\mathrm{MS}^{\mathrm{n}}$ spectra (fragmentation pattern) with authentic standards.

\subsection{Isolation of pinoresinol (3) from fungally infected pea pods}

The EtOAc extract from fungally infected pea pods was sequentially purified by preparative silica gel TLC (eluant, $\mathrm{CH}_{2} \mathrm{Cl}_{2}-\mathrm{MeOH}, 9: 1$ ) and then by reversed-phase HPLC to afford pinoresinol (3), with the latter subsequently subjected to chiral HPLC analysis (see "Instrumentation and Chromatography Materials").

\subsection{Isolation of pinoresinol-4'-O- $\beta$-D-monoglucoside (4) from fungal infected pea pods}

Fungally infected pea pods (2.4 g), as above, were subjected to metabolite extraction using $\mathrm{MeOH}-\mathrm{H}_{2} \mathrm{O}(70: 30, \mathrm{v} / \mathrm{v})(3 \times 400 \mathrm{ml})$, with extracts centrifuged $(3000 \times \mathrm{g}$ for $5 \mathrm{~min})$ and evaporated to dryness in vacuo. Further purification was done using a reversed-phase HPLC system. Purified fractions were combined and subjected to reversed-phase UPLC-MS and ion mobility mass spectrometric analyses, as described above (see "Instrumentation and Chromatography Materials").

\subsection{Chemical synthesis of pinoresinol-4'-O- $\beta$-D-monoglucoside (4)}


This was carried out as previously described (Vermes et al., 1991) with the following modifications. To a solution of ( \pm )-pinoresinol (3) (89 $\mathrm{mg}, 0.25 \mathrm{mmol})$ in $\mathrm{Me}_{2} \mathrm{CO}(6 \mathrm{ml})$ and $2.5 \% \mathrm{KOH}(0.68 \mathrm{ml}, 0.3 \mathrm{mmol})$ a solution of 2,3,4,6-tetra- $O$-acetyl- $\alpha$-D-glucopyranosyl bromide $(127.5 \mathrm{mg}, 0.3 \mathrm{mmol})$ in $\mathrm{Me}_{2} \mathrm{CO}(4 \mathrm{ml})$ was added dropwise at $0^{\circ} \mathrm{C}$. After stirring for $1.5 \mathrm{~h}$ at $0^{\circ} \mathrm{C}$ and standing overnight at $5^{\circ} \mathrm{C}$, the solvent was then evaporated in vacuo, with the resulting residue diluted with $\mathrm{H}_{2} \mathrm{O}(5 \mathrm{ml})$ and the whole extracted with EtOAc $(10 \mathrm{ml})$. The residue was dissolved in $\mathrm{MeOH}(20 \mathrm{ml})$, with the solution adjusted to $\mathrm{pH} 10$ with $1 \mathrm{M} \mathrm{NaOMe}$ and left standing overnight at room temperature. After neutralization with Amberlite IR-120 cation exchange resin, filtration and evaporation, the resulting residue was applied to a neutral $\mathrm{Al}_{2} \mathrm{O}_{3}$ column and eluted with EtOAc-MeOH-H${ }_{2} \mathrm{O}, 350 \mathrm{ml}, 200: 33: 27$ (v/v). After some unreacted aglycone (3) (28 mg, 31.5\%) was eluted first, pinoresinol-4'-O- $\beta$-D-monoglucoside (4) was collected, with the corresponding eluate evaporated to give a clear oil which slowly solidified as an amorphous product (42.5 mg, 33\%). MS, ${ }^{1} \mathrm{H},{ }^{13} \mathrm{C} \mathrm{NMR}$, and UV spectroscopic analyses of pinoresinol-4'-O- $\beta$-D-monoglucoside (4) were in agreement with published data (Vermes et al., 1991). The coupling constant $(J=7.5 \mathrm{~Hz})$ of the anomeric $\mathrm{H}$ atom confirmed that the glucopyranosyl unit existed in a $\beta$-configuration.

\subsection{Gene expression analysis}

Total RNA ( $5 \mu \mathrm{g}$ ) was individually isolated from uninfected and fungally infected pea pods using the RNeasy plant Minikit (Qiagen), with first strand cDNA (1 $\mu \mathrm{g})$ synthesized using the SuperScript $^{\mathrm{TM}}$ III First-Strand Synthesis System for RT-PCR (Invitrogen). For real time quantitative PCR analyses, each PCR mixture contained synthesized first strand cDNA, Platinum SYBR Green qPCR SuperMix-UDG (Invitrogen) and gene-specific primers, which were designed using Primer Premier software (Biosoft International, Palo Alto, CA) (Supplemental Table S1). Expression levels were normalized against the pea actin gene with expression levels for the DRR206 gene in uninfected pea pods set to 1 and data averaged from triplicate samples

\subsection{Cloning and construction of the DRR206 expression vector}

Vector construction and transformation were carried out as described by Kim et al. (2012). The DRR206 gene (GenBank U11716) was PCR amplified using gene specific primers (Forward $5^{\prime}-$ and Reverse

$5^{\prime}-$ 

sequence was re-amplified with the linker primers (Forward 5'GGAATTCATGGGTTCCAAACTTCTA-3' ${ }^{\prime}$ and 5'GAAGCTTTTACCAACACTCAAAGAA-3') which harbored restriction enzyme sites designed for directional cloning into the pART7 vector. After digestion of PCR products with EcoRI and HindIII digestion, the DNA fragments were ligated with pART17 vector which was also digested with the same restriction enzymes. After sequence verification, the biolistic bombardment technology was employed to introduce the DRR206-harboring pART17 into tomato (Solanum peruvianum) cells (Kim et al., 2012). Tomato calli were produced on media containing kanamycin $(75 \mu \mathrm{g} / \mathrm{ml})$ and the gene expression level of DRR206 in each tomato callus was assessed using RT-PCR. Six calli preparations were selected for cell suspension culture production of the DRR206 recombinant protein.

\subsection{Heterologous expression and purification of DRR206 in plant cell cultures}

Expression and purification of the DRR206 recombinant protein in tomato cell culture were carried out according to the procedures described in Kim et al. (2012). Transformed suspension cell cultures (40 ml each) were gradually scaled-up weekly by inoculating them into new media (up to $3 \mathrm{~L}$ ). Seven days after final inoculation, cells were harvested by vacuum filtration. "Cell wall bound" proteins were recovered after stirring the cells in KPi buffer (0.1 M, pH 5.9; buffer A) first containing $75 \mathrm{mM} \mathrm{KCl}$ and then $150 \mathrm{mM} \mathrm{KCl}$. After agitating the cell suspension for 30 minutes at $100 \mathrm{rpm}$ at $4{ }^{\circ} \mathrm{C}$, both buffered solutions were recovered by vacuum filtration, combined and mixed with SP-Sepharose fast flow ${ }^{\circledR}$ resin $(80 \mathrm{ml})$ pre-equilibrated with buffer A containing $75 \mathrm{mM} \mathrm{KCl}$. Proteins were eluted with buffer A containing $1 \mathrm{M} \mathrm{NaCl}$, followed by $\left(\mathrm{NH}_{4}\right)_{2} \mathrm{SO}_{4}$ fractionation. Proteins precipitating between 40 and $80 \%\left(\mathrm{NH}_{4}\right)_{2} \mathrm{SO}_{4}$ saturation were recovered after centrifugation for $30 \mathrm{~min}$ at $10,000 \times \mathrm{g}$, re-suspended in $40 \mathrm{mM}$ MES buffer $(\mathrm{pH}$ 5.0), concentrated, and desalted using an Amicon Centricon ${ }^{\circledR}$ filtration apparatus. Each concentrate was then applied onto a Mono STM 5/50 column $(5 \times 50 \mathrm{~mm}$, GE Healthcare $)$ preequilibrated with $40 \mathrm{mM}$ MES buffer ( $\mathrm{pH}$ 5.0) at a flow rate of $1 \mathrm{ml} \mathrm{min-1.} \mathrm{DRR206} \mathrm{proteins}$ were eluted using a step gradient of $\mathrm{Na}_{2} \mathrm{SO}_{4}(0$ to $333 \mathrm{mM}$ ) in $40 \mathrm{mM}$ MES buffer (pH 5.0). After desalting, each sample was applied onto a POROS® 20 SP column pre-equilibrated with 
HEPES-sodium acetate-MES buffer (33 mM each, $\mathrm{pH} 5.0$ ) at a flow rate of $1.5 \mathrm{ml} \mathrm{min}-1$. DRR206 proteins were eluted with $333 \mathrm{mM} \mathrm{Na}_{2} \mathrm{SO}_{4}$, and desalted.

\subsection{Dirigent protein assays}

Purified recombinant DRR206 protein was assayed in a similar way as described in Kim et al. (2012), with the assay reactions containing each of $0.2,0.4,0.8,1.6,3.2,4.8$, and $6.4 \mu \mathrm{M}$ of DRR206 protein, Trametes versicolor laccase as an oxidizing agent, and $300 \mu \mathrm{M}$ coniferyl alcohol (2) in $40 \mathrm{mM}$ MES buffer ( $\mathrm{pH} 5.0)$ in a total volume of $250 \mu$. Total protein concentration in the assays was kept constant with bovine serum albumin (Promega). After each reaction, assay mixtures were individually extracted with EtOAc $(500 \mu \mathrm{l} \times 2)$ after $4 \mathrm{~h}$ of shaking incubation in a $30{ }^{\circ} \mathrm{C}$ water bath. Dried EtOAc solubles were dissolved in $\mathrm{MeOH}-\mathrm{H}_{2} \mathrm{O}(7: 3$, v/v) and subjected to reversed-phase HPLC analyses as described in section 4.1. Assays were also carried out using above conditions, but with $400 \mu \mathrm{M} p$-coumaryl alcohol (5) as the substrate.

\subsection{Preparation of plant material for MALDI imaging and matrix application}

Surface tissue sections were obtained from fresh pea (Pisum sativum cv. Alcan) pods and were inoculated with fungal spores as described above. After $6 \mathrm{~h}$ infection, the tissues were subjected to a rapid $(15 \mathrm{sec})$ hexane dip to largely remove the waxy layer to facilitate the laser ablation on the tissue. Next, the epidermal cell layer of half of the tissue was removed by making a clean cut at one end and pulling forward using fine forceps. Surface tissue samples with and without endocarp epidermal cells were placed on a MALDI imaging plate using double-sided tape $\left(\operatorname{Scotch}^{\circledR} 3 \mathrm{M}\right)$ followed by obtaining optical images of samples using a standard flatbed scanner (Epson Perfection V600 photo). Tissue samples were then sprayed with DHB matrix (40 $\mathrm{mg} / \mathrm{ml}$ in $\mathrm{MeOH}-\mathrm{H}_{2} \mathrm{O}$ (which contains 0.1\% TFA) 70:30, v/v) using the HTX TM-Sprayer with optimized conditions at a flow rate of $100 \mu \mathrm{min}^{-1}$.

\subsection{MALDI Imaging mass spectrometry, ion mobility separation and data analysis}

MALDI tissue imaging experiments were carried out using a Synapt G2 HDMS (MALDI QTOF MS, Waters Corp., Manchester, UK), a hybrid quadrupole, and an ion mobility time-offlight mass spectrometer equipped with MALDI source. It was fitted with a $1 \mathrm{kHz}$ solid state $\mathrm{Nd}$ : YAG laser $(\lambda=355 \mathrm{~nm})$, which was used in the resolution mode and positive polarity for data 
acquisition. Calibration was with red phosphorus (10 $\mathrm{mg} / \mathrm{ml}$ in acetone), with leucine ion enkephalin $\left([\mathrm{M}+\mathrm{H}]^{+}=556.2771\right)$ used as reference mass. The data were acquired in the positive mode with acquisition mass range set from $\mathrm{m} / \mathrm{z} 100$ to $1000 \mathrm{Da}$ to cover the mass range of pisatin (1) and pinoresinol monoglucoside (4), in resolution mode with spatial resolution of $75 \mu \mathrm{m}$ at laser energy of 450. About 3796 laser shots were carried out in order to create a MALDI ion image of the pea pod surface tissue over an area of $21.4 \mathrm{~mm}^{2}$ at a sampling rate of $0.5 \mathrm{sec}$ per

pixel. Raw data were then processed and ion maps were visualized in HDImaging ${ }^{\mathrm{TM}}$ software. Chemical identities of metabolites observed were confirmed by comparing MS, mass accuracy values and drift times of authentic standards.

\section{Acknowledgements}

The authors wish to express thanks to Prof. Lee A. Hadwiger, Department of Plant Pathology, Washington State University, Pullman, WA, for a gift of the Fusarium solani f. sp. phaseoli strain, and Prof. Hans D. VanEtten, School of Plant Sciences, University of Arizona, Tucson, AZ, for providing an authentic (+)-pisatin standard.

This work was funded by the National Science Foundation (MCB-1052557), the Chemical Sciences, Geosciences and Biosciences Division, Office of Basic Energy Sciences, Office of Science, U.S. Department of Energy (DE-FG-0397ER20259) and the G. Thomas and Anita Hargrove Center for Plant Genomic Research, for generous financial support. MALDI-MS based imaging analysis was performed on an instrument acquired through a Major Research Instrumentation grant (DBI-1229749) from the National Science Foundation. Metabolite isolation, identification and in situ localization (using MALDI-IMS) was supported by the DOE, with instrumentation being from the NSF MRI support. 
Table 1. Ultra performance liquid chromatography quadropole time of flight mass spectrometry, UPLC-qToF-MS and ion mobility separation analyses results

\begin{tabular}{lccc}
\hline Pinoresinol monoglucoside (4) & Mode & $m / z$ & Drift time (bins) \\
\hline Standard & Positive & {$[\mathrm{M}+\mathrm{Na}]^{+} 543.1850(-1.4 \mathrm{ppm})$} & 85.625 \\
Isolated from infected pea pods & & {$[\mathrm{M}+\mathrm{Na}]^{+} 543.1852(-1.8 \mathrm{ppm})$} & 85.785 \\
Standard & Negative & {$[\mathrm{M}-\mathrm{H}]^{-} 519.1863(0.5 \mathrm{ppm})$} & 100.568 \\
Isolated from infected pea pods & & {$[\mathrm{M}-\mathrm{H}]^{-} 519.1868(-0.3 \mathrm{ppm})$} & 100.693 \\
\hline
\end{tabular}

Table 2. MALDI imaging mass spectrometry with ion mobility separation results showing $\mathrm{m} / \mathrm{z}$ values and drift times of pisatin (1) and pinoresinol monoglucoside (4)

\begin{tabular}{|l|c|c|c|c|}
\hline \multirow{2}{*}{} & \multicolumn{2}{|c|}{$\begin{array}{c}\text { Pisatin (1) } \\
{\left[\mathrm{M}-\mathrm{H}_{2} \mathrm{O}+\mathrm{H}\right]^{+}}\end{array}$} & \multicolumn{2}{c|}{$\begin{array}{c}\text { Pinoresinol monoglucoside (4) } \\
{[\mathrm{M}+\mathrm{K}]^{+}}\end{array}$} \\
\hline & $\mathrm{m} / z(\mathrm{ppm})$ & drift time (bins) & $m / z(\mathrm{ppm})$ & drift time (bins) \\
\hline Standard & 297.0749 & 27.85 & 559.1594 & 51.93 \\
& $\Delta$ ppm: 4.7 & & $\Delta$ ppm: -2.1 & \\
\hline $\begin{array}{l}\text { In fungal infected pea } \\
\text { pod surface section }\end{array}$ & $\begin{array}{c}297.0753 \\
\Delta \text { ppm: } 3.3\end{array}$ & 27.75 & $\begin{array}{c}559.1590 \\
\Delta \text { ppm: }-1.4\end{array}$ & 52.11 \\
\hline
\end{tabular}




\section{Figure Legends}

Fig. 1. Sequence alignments of pea DRR206 (PsDRR206) and Forsythia intermedia (+)pinoresinol forming dirigent protein (FiDir).

Fig. 2. DRR206 gene expression analysis following fungal infection using real time quantitative PCR. Expression level of DRR206 was set to 1 for uninfected pea pod tissue, with expression of the pea actin gene used as an internal control. Error bars represent standard deviation of three replicates.

Fig. 3. DRR206 protein-mediated coupling of coniferyl alcohol (2) showing the effect of varying DRR206 concentrations on the formation of (+)-pinoresinol (3a).

Fig. 4. UPLC chromatograms. A. Extract from uninfected pea pods. B. Extract from infected pea pods. C. Pinoresinol monoglucoside (4) standard.

Fig. 5. Pea pod anatomy and MALDI imaging of pisatin (1) and pinoresinol monoglucoside (4). A. Cross-section of pea pod stained with toluidine blue O. B - G. MALDI IMS positive ion images of pisatin $\left(\mathbf{1} ; \mathrm{m} / \mathrm{z}\right.$ 297.0753, $\left.\left[\mathrm{M}-\mathrm{H}_{2} \mathrm{O}+\mathrm{H}\right]^{+} ; \mathbf{B}-\mathbf{D}\right)$ and pinoresinol monoglucoside $(\mathbf{4} ; \mathrm{m} / z$ 559.1590, $\left.[\mathrm{M}+\mathrm{K}]^{+} ; \mathbf{E}-\mathbf{G}\right)$ at ratios of histology image layer:data image layer of 100:100 (B, E), 25:50 (C, F) and 0:100 (D, G), respectively.

Fig. 6. DRR206 and CHS gene expression analysis in pea pods by quantitative real time PCR. Expression levels of DRR206 (A) and CHS (B) in pea pods with endocarp epidermal cell layer, endocarp epidermal cell layer, and pea pods without endocarp epidermal cell layer $6 \mathrm{~h}$ after exposure to F. solani. Expression level of DRR206 and CHS were set to 1 in uninfected pea pod tissue (control), with expression of the pea actin gene used as an internal control. Error bars represent standard deviation of three replicates. 


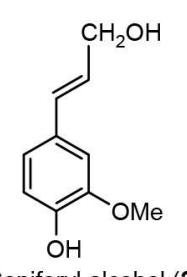

(+)-Pisatin (1)

Coniferyl alcohol (2)

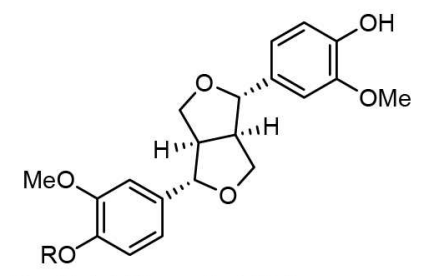

$\mathrm{R}=\mathrm{H},(+)$-Pinoresinol (3a)

$\mathrm{R}=$ Glc, $(+)$-Pinoresinol glucoside (4a) $\mathrm{R}=\mathrm{Glc},(-)$-Pinoresinol glucoside (4b)
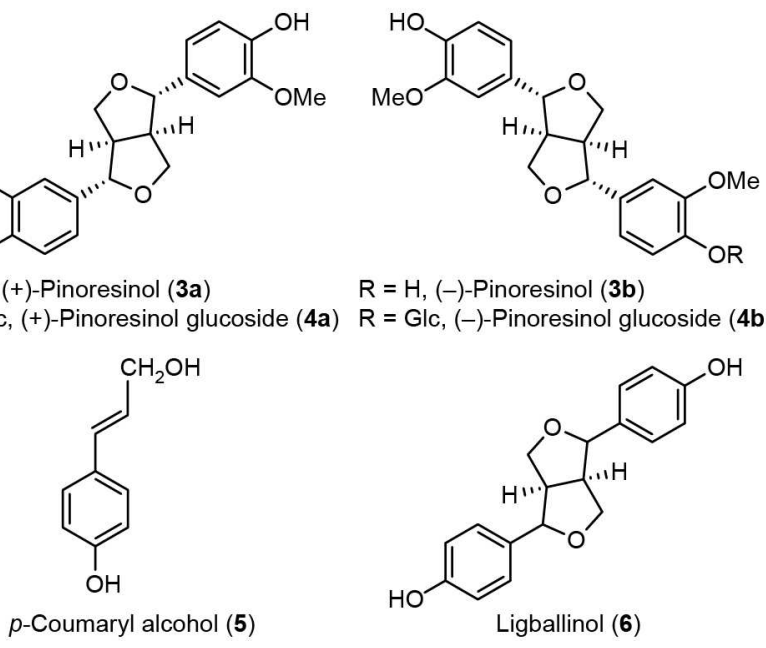

$\mathrm{R}=\mathrm{H},(-)$-Pinoresinol $(\mathbf{3 b})$

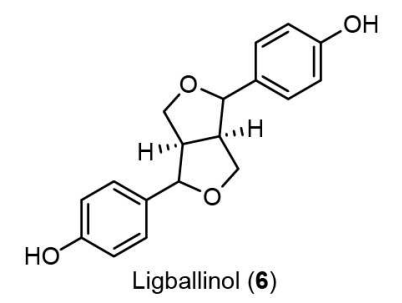

\section{Scheme 1}

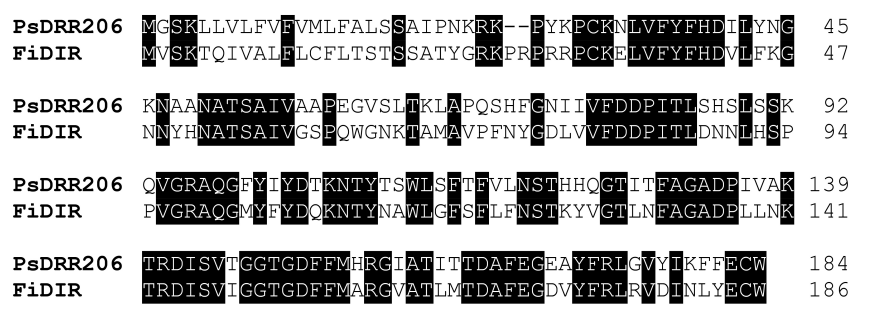

Figure 1 


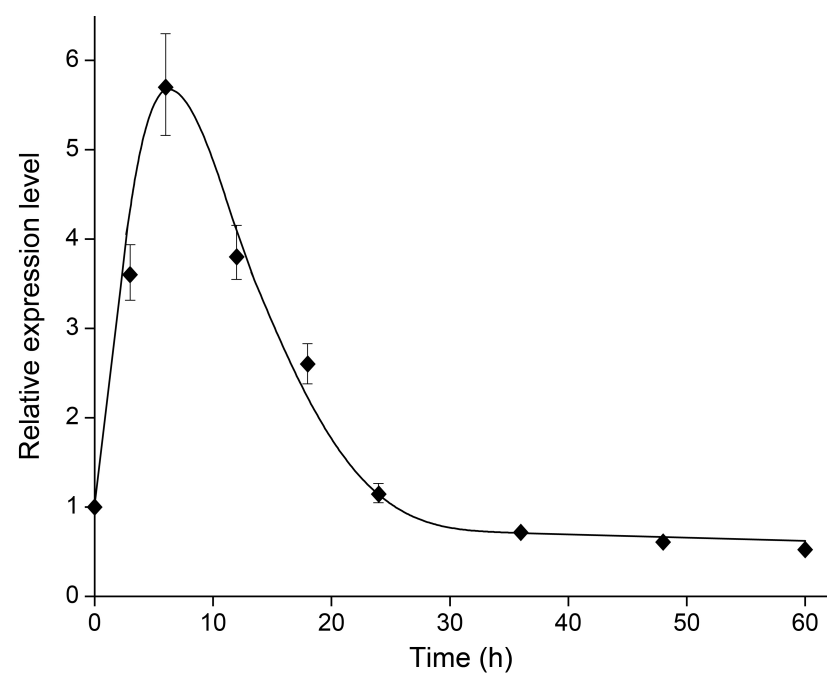

Figure 2

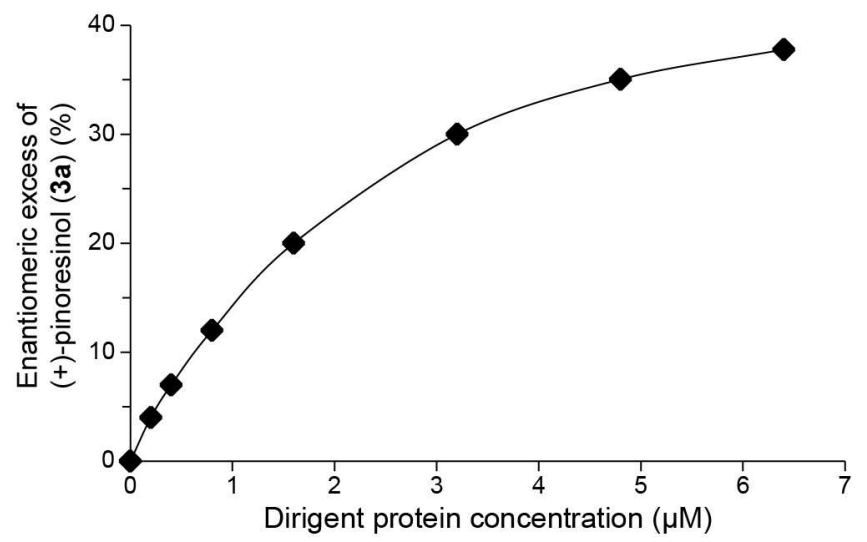

Figure 3

47

48

49

50

51

52

53

54

55

56

57

58

59

60

61

62

63 


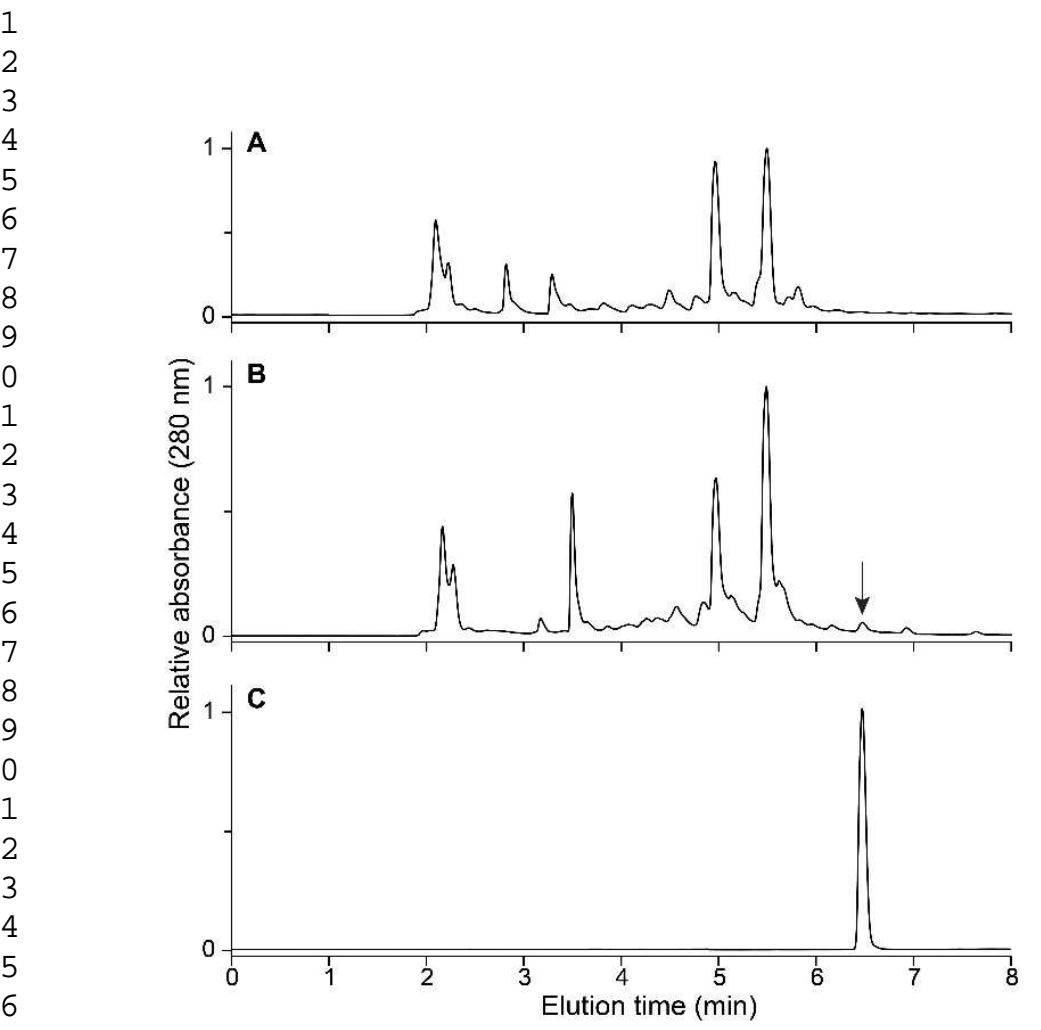



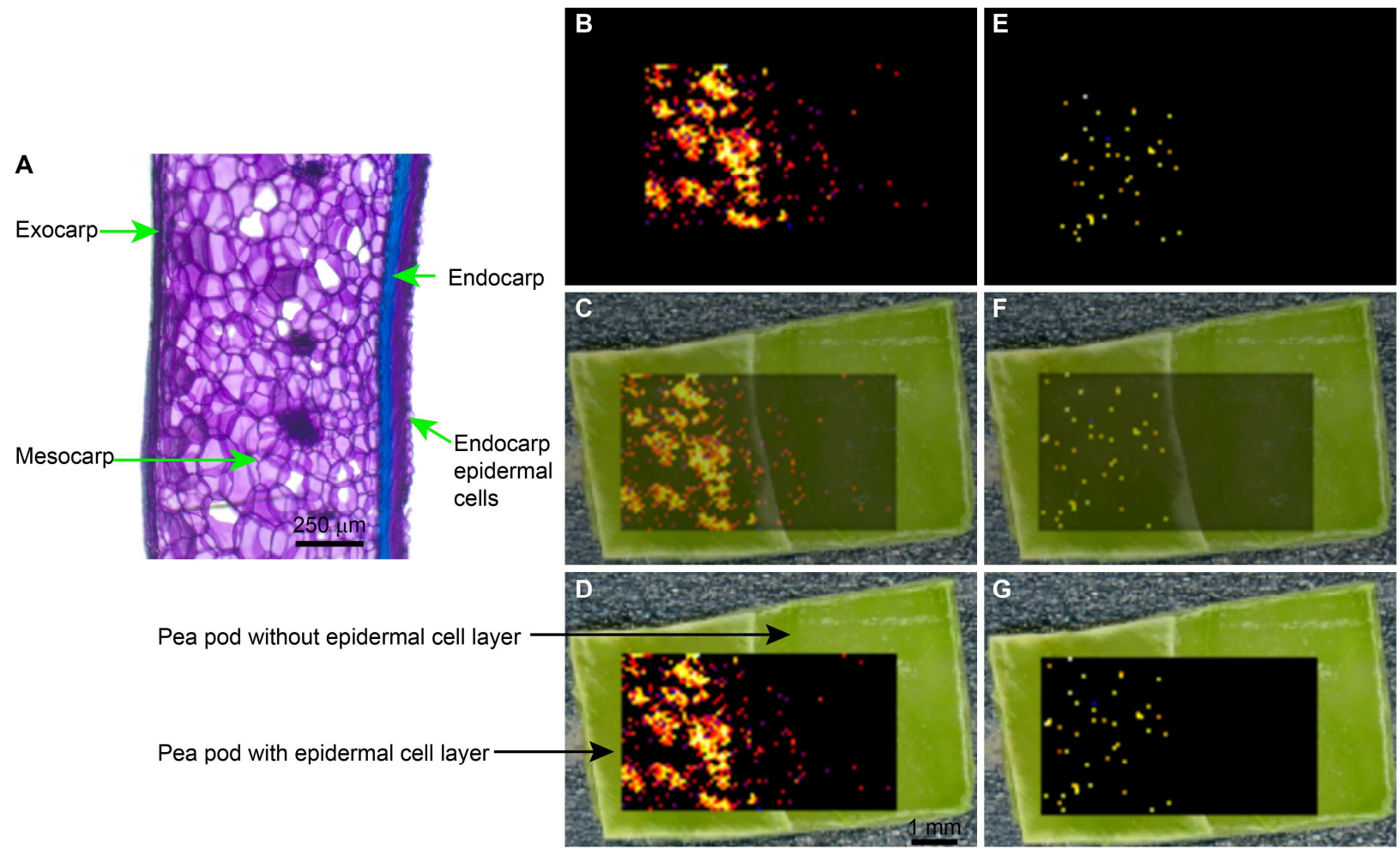

Figure 5 


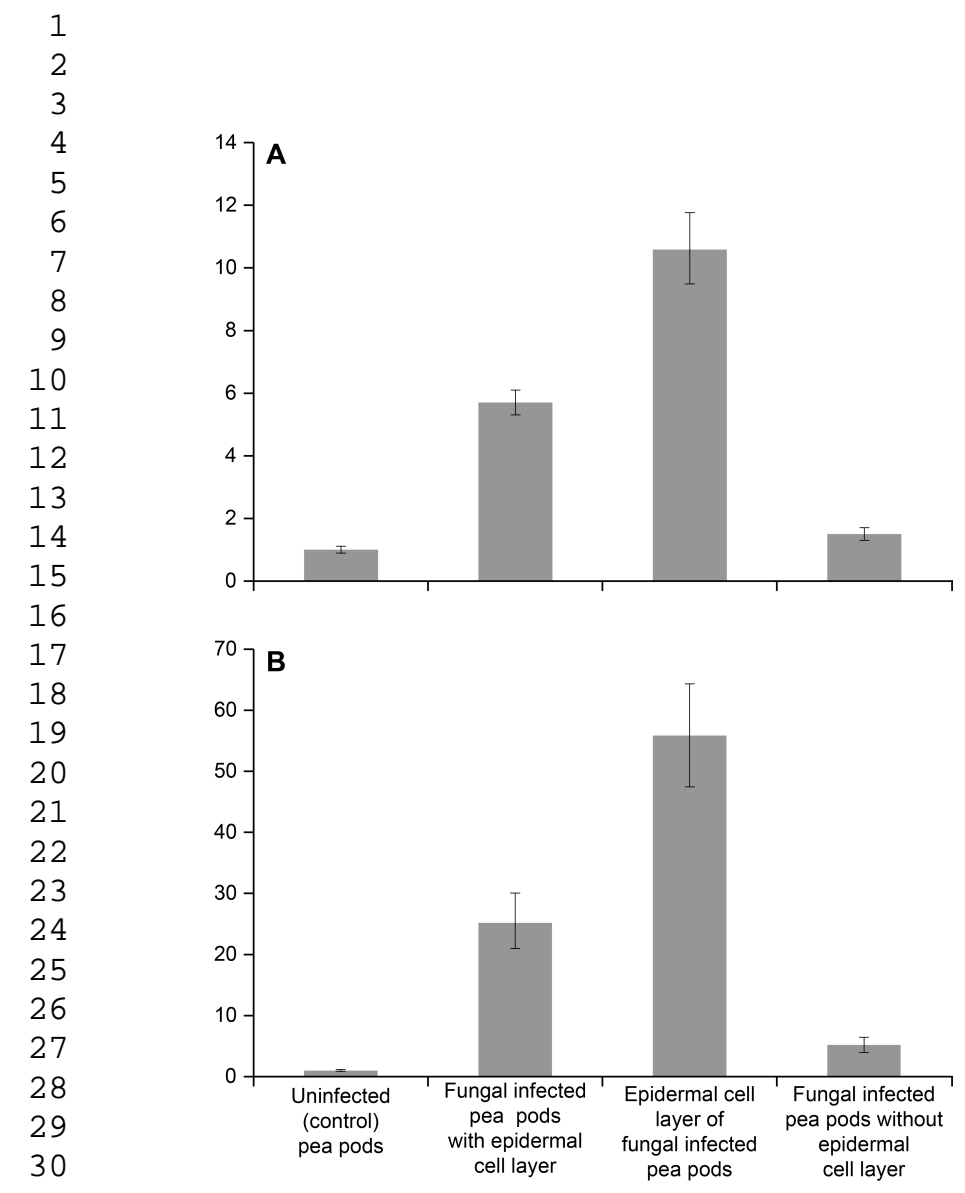

Figure 6

34

35

36 


\section{References}

Atkins, C. A., Kuo, J., Pate, J. S., Flinn, A. M., Steele, T. W., 1977. Photosynthetic pod wall of pea (Pisum sativum L.): Distribution of carbon dioxide-fixing enzymes in relation to pod structure. Plant Physiol. 60, 779-786.

Banks, S. W., Dewick, P. M., 1983. Biosynthesis of pisatin: Experiments with enantiomeric precursors. Phytochemistry 22, 1591-1595.

Bednarek, P., Osbourn, A., 2009. Plant-microbe interactions: Chemical diversity in plant defense. Science 324, 746-748.

Bednarek, P., Schneider, B., Svatoš, A., Oldham, N. J., Hahlbrock, K., 2005. Structural complexity, differential response to infection, and tissue specificity of indolic and phenylpropanoid secondary metabolism in Arabidopsis roots. Plant Physiol. 138, 1058-1070.

Bomi, H., Juneyoung, L., Qing-He, L., Eun-Rhan, W., Dong Gun, L., 2010. Antifungal effect of (+)-pinoresinol isolated from Sambucus williamsii. Molecules 15, 3507-3516.

Celoy, R. M., VanEtten, H. D., 2014. (+)-Pisatin biosynthesis: From (-) enantiomeric intermediates via an achiral 7,2'-dihydroxy-4',5'-methylenedioxyisoflav-3-ene. Phytochemistry 98, 120-127.

Choi, J. J., Klosterman, S. J., Hadwiger, L. A., 2001. A comparison of the effects of DNAdamaging agents and biotic elicitors on the induction of plant defense genes, nuclear distortion, and cell death. Plant Physiol. 125, 752-762.

Chu, A., Dinkova, A., Davin, L. B., Bedgar, D. L., Lewis, N. G., 1993. Stereospecificity of (+)pinoresinol and (+)-lariciresinol reductases from Forsythia intermedia. J. Biol. Chem. 268, 27026-27033.

Churngchow, N., Rattarasarn, M., 2001. Biosynthesis of scopoletin in Hevea brasiliensis leaves inoculated with Phytophthora palmivora. J. Plant Physiol. 158, 875-882.

Cruickshank, I. A. M., R Perrin, D., 1963. Studies on phytoalexins VI. Pisatin: The effect of some factors on its formation in Pisum sativum L., and the significance of pisatin in disease resistance. Aust. J. Biol. Sci. 16, 111-128.

Culley, D. E., Horovitz, D., Hadwiger, L. A., 1995. Molecular characterization of diseaseresistance response gene DRR206-d from Pisum sativum (L.). Plant Physiol. 107, 301-302.

Davin, L. B., Lewis, N. G., 2000. Dirigent proteins and dirigent sites explain the mystery of specificity of radical precursor coupling in lignan and lignin biosynthesis. Plant Physiol. 123, 453-462.

Davin, L. B., Lewis, N. G., 2005. Lignin primary structures and dirigent sites. Curr. Opin. Biotechnol. 16, 407-415.

Davin, L. B., Wang, H.-B., Crowell, A. L., Bedgar, D. L., Martin, D. M., Sarkanen, S., Lewis, N. G., 1997. Stereoselective bimolecular phenoxy radical coupling by an auxiliary (dirigent) protein without an active center. Science 275, 362-367.

DiCenzo, G. L., VanEtten, H. D., 2006. Studies on the late steps of (+) pisatin biosynthesis: Evidence for (-)-enantiomeric intermediates. Phytochemistry 67, 675-683.

Dixon, R. A., 2001. Natural products and plant disease resistance. Nature 411, 843-847.

Dixon, R. A., Pasinetti, G. M., 2010. Flavonoids isoflavonoids: From plant biology to agriculture and neuroscience. Plant Physiol. 154, 453-457.

Fristensky, B., Horovitz, D., Hadwiger, L., 1988. cDNA sequences for pea disease resistance response genes. Plant Mol. Biol. 11, 713-715. 
Gang, D. R., Costa, M. A., Fujita, M., Dinkova-Kostova, A. T., Wang, H.-B., Burlat, V., Martin, W., Sarkanen, S., Davin, L. B., Lewis, N. G., 1999. Regiochemical control of monolignol radical coupling: A new paradigm for lignin and lignan biosynthesis. Chem. Biol. 6, 143151.

Hadwiger, L. A., 1966. The biosynthesis of pisatin. Phytochemistry 5, 523-525.

Hadwiger, L. A., 2008. Pea-Fusarium solani interactions. Contributions of a system toward understanding disease resistance. Phytopathology 98, 372-379.

Hadwiger, L. A., Chang, M.-M., Parsons, M. A., 1995. Fusarium solani DNase is a signal for increasing expression of nonhost disease resistance response genes, hypersensitivity, and pisatin production. Mol. Plant-Microbe Interact. 8, 871-879.

Halkier, B. A., Gershenzon, J., 2006. Biology and biochemistry of glucosinolates. Annu. Rev. Plant Biol. 57, 303-333.

Halls, S. C., Davin, L. B., Kramer, D. M., Lewis, N. G., 2004. Kinetic study of coniferyl alcohol radical binding to the (+)-pinoresinol forming dirigent protein. Biochemistry 43, 2587-2595.

Halls, S. C., Lewis, N. G., 2002. Secondary and quaternary structures of the (+)-pinoresinolforming dirigent protein. Biochemistry 41, 9455-9461.

Hammerschmidt, R., 1999. Phytoalexins: What have we learned after 60 years? Annu. Rev. Phytopathol. 37, 285-306.

Harborne, J. B., 1994. The Flavonoids: Advances in Research since 1986. Chapman \& Hall, New York, NY.

Harborne, J. B., Williams, C. A., 2000. Advances in flavonoid research since 1992. Phytochemistry 55, 481-504.

Hosmani, P. S., Kamiya, T., Danku, J., Naseer, S., Geldner, N., Guerinot, M. L., Salt, D. E., 2013. Dirigent domain-containing protein is part of the machinery required for formation of the lignin-based Casparian strip in the root. Proc. Natl. Acad. Sci. USA 110, 14498-14503.

Kim, K.-W., Moinuddin, S. G. A., Atwell, K. M., Costa, M. A., Davin, L. B., Lewis, N. G., 2012. Opposite stereoselectivities of dirigent proteins in Arabidopsis and Schizandra species. J. Biol. Chem. 287, 33957-33972.

Lankau, R. A., 2007. Specialist and generalist herbivores exert opposing selection on a chemical defense. New Phytol. 175, 176-184.

Lankau, R. A., Strauss, S. Y., 2007. Mutual feedbacks maintain both genetic and species diversity in a plant community. Science 317, 1561-1563.

Nakatsubo, T., Mizutani, M., Suzuki, S., Hattori, T., Umezawa, T., 2008. Characterization of Arabidopsis thaliana pinoresinol reductase, a new type of enzyme involved in lignan biosynthesis. J. Biol. Chem. 283, 15550-15557.

Pickel, B., Constantin, M. A., Pfannstiel, J., Conrad, J., Beifuss, U., Schaller, A., 2010. An enantiocomplementary dirigent protein for the enantioselective laccase-catalyzed oxidative coupling of phenols. Angew. Chem. Int. Ed. Engl. 49, 202-204.

Riggleman, R., Fristensky, B., Hadwiger, L., 1985. The disease resistance response in pea is associated with increased levels of specific mRNAs. Plant Mol. Biol. 4, 81-86.

Smith, C. J., 1996. Accumulation of phytoalexins: Defence mechanism and stimulus response system. New Phytol. 132, 1-45. 
Teasdale, J., Daniels, D., Davis, W. C., Eddy, R., Hadwiger, L. A., 1974. Physiological and cytological similarities between disease resistance and cellular incompatibility responses. Plant Physiol. 54, 690-695.

VanEtten, H. D., Mansfield, J. W., Bailey, J. A., Farmer, E. E., 1994. Two classes of plant antibiotics: phytoalexins versus "phytoanticipins". Plant Cell 6, 1191-1192.

Vassão, D. G., Kim, K.-W., Davin, L. B., Lewis, N. G., 2010. Lignans (neolignans) and allyl/propenyl phenols: Biogenesis, structural biology, and biological/human health considerations. In: Townsend, C., Ebizuka, Y. (Eds.), Comprehensive Natural Products Chemistry II, vol. 1: Structural Diversity I. Elsevier, Oxford, UK, pp. 815-928.

Vermes, B., Seligmann, O., Wagner, H., 1991. Synthesis of biologically active tetrahydrofurofuranlignan-(syringin, pinoresinol)- mono- and bis-glucosides. Phytochemistry 30, 30873089.

Wang, Y., Fristensky, B., 2001. Transgenic canola lines expressing pea defense gene DRR206 have resistance to aggressive blackleg isolates and to Rhizoctonia solani. Mol. Breed. 8, 263271.

Yamamoto, S., Cox, R. E., Simoneit, B. R. T., 2010. Gas chromatography/mass spectrometry of the lignans in resin of Callitris preissii. J. Mass Spec. Soc. Jap. 58, 195-209.

Zook, M., Hammerschmidt, R., 1997. Origin of the thiazole ring of camalexin, a phytoalexin from Arabidopsis thaliana. Plant Physiol. 113, 463-468.

Züst, T., Heichinger, C., Grossniklaus, U., Harrington, R., Kliebenstein, D. J., Turnbull, L. A., 2012. Natural enemies drive geographic variation in plant defenses. Science 338, 116-119. 